\title{
Automaty, hybrydy, afekty - posthumanistyczne konteksty aparatu gry komputerowej i praktyk grania
}

Jan Stasieńko 


\section{Automaty, hybrydy, afekty - posthumanistyczne konteksty aparatu gry komputerowej i praktyk grania}

Jan Stasieńko

TEKSTY DRUGIE 2017, NR 3, S. 32-50

DOI: $10.18318 /$ td.2017.3.3

ntensywnie rozwijająca się refleksja nad posthumanizmem i transhumanizmem dotyka obecnie bardzo wielu pól i obszarów badawczych i jest prowadzona z perspektywy różnych dyscyplin i szkół naukowych. Gry komputerowe są sferą, która także ma wiele takich kontekstów, w ramach których można śledzić obecność idei post- i transhumanistycznej na bardzo wielu poziomach. Mam tu na myśli zarówno wykorzystanie tej idei do praktyki projektowania gier w kontekście ich mechaniki, fabuły oraz interfejsu, ale także do śledzenia specyficznych kontekstów odbiorczych gier oraz wypracowywanych od pewnego czasu ,nieatropocentrycznych” narzędzi ich badania. Niebagatelne znaczenie ma także krytyczny kontekst postrzegania gier w perspektywie posthumanizmu. Jak pisze Boulder, „Granie jest zdarzeniem, które w sposób radykalny kwestionuje naturę doświadczenia i jaźni, to zdarzenie, które tak naprawdę może wytworzyć całkowicie nowe doświadczenie «ja»"1.

1 J. Boulder Parables of the Posthuman: Digital Realities, Gaming, and the Player Experience, Wayne State University Press, Detroit, MI 2015, s. 2.
Jan Stasieńko - prof. DSW, dr hab., dyrektor Instytutu Dziennikarstwa i Komunikacji Społecznej oraz Centrum Badawczo-Projektowego Gier i Animacji „Digital Masters" w Dolnośląskiej Szkole Wyższej. Interesuje się ludologią, archeologią nowych mediów, posthumanizmem, antropologią efektów specjalnych. Ostatnio opublikował Niematerialne Galatee w wehikułach rozkoszy i bólu... (2015) oraz Capturing motor competencies. People with Disabilities as Actors in Motion Capture Sessions (2015). 
W omawianych zakresach wychodzę z założenia, że pojmowanie gry komputerowej jako wielowarstwowego produktu cyfrowego dostępnego dla gracza za pośrednictwem interfejsu definiuje ją jako pasywny obiekt działania użytkownika. Obecność w strukturze gry sztucznej inteligencji, jej generatywność, a także złożone problemy agentywności i skomplikowane relacje między graczem i awatarem sprawiają, że ostre podziały na sferę przedmiotową i podmiotową, pasywną i aktywną czy nawet między graczem a grą wymagają przepracowania i są w tej chwili redefiniowane w wielu koncepcjach badawczych.

Niniejszy artykuł jest próbą nakreślenia pól tych redefinicji i wykazaniem potencjału myśli posthumanistycznej dla badań nad grami. Głównym celem tego tekstu jest w związku z tym określenie i omówienie poziomów wykorzystania idei posthumanizmu w grach. W artykule wskażę następujące poziomy, na których ujawniają się posthumanistyczne konteksty gier: aparatu gry, fabularny, genologiczny, poziom agentywności i mechaniki gry, interfejsu i praktyk grania.

\section{Poziom aparatu gry}

W ramach tego poziomu chciałbym określić kilka wybranych cech aparatu gry definiowanego w perspektywie post- $\mathrm{i}$ transhumanizmu. W rozdziale pierwszym niedawno opublikowanej pracy Examining the Evolution of Gaming and Its Impact on Social, Cultural, and Political Perspectives Advances in Human and Social Aspects of Technology ${ }^{2}$ jego autorzy, Jensen, Barreto i Valentine ${ }^{3}$, rozprawiają się po kolei z różnymi elementami uznanych definicji gry wideo sformułowanych m.in. przez Juula ${ }^{4}$, Salen i Zimmermanna ${ }^{5}$, McGonigal $^{6}$. Definicje te były formułowane z punktu widzenia zarówno projektantów gier, jak i badaczy

2 Examining the Evolution of Gaming and Its Impact on Social, Cultural, and Political Perspectives Advances in Human and Social Aspects of Technology, ed. by K. Valentine, L. Jensen, IGI Global, Hershey, PA 2016.

3 L. Jensen, D. Barreto, K.D. Valentine Toward Broader Definitions of "Video Games": Shifts in Narrative, Player Goals, Subject Matter, and Digital Play Environments, w: Examining the Evolution..., s. 1-37.

4 J. Juul Half-Real: Video Games Between Real Rules and Fictional Worlds, The MIT Press, Cambridge, MA-London 2011.

5 K. Salen, E. Zimmerman Rules of Play: Game Design Fundamentals, The MIT Press, Cambridge, MA-London 2004.

6 J. McGonigal Reality Is Broken: Why Games Make Us Better and How They Can Change the World, Penguin Press, New York 2011. 
reprezentujących różne nurty ludologii i kładły nacisk na zróżnicowane elementy gier i aspekty samej czynności grania, wiążąc się przede wszystkim z określonymi regułami rozgrywki i mechaniki gier, określały warunki wygranej w grze itd. Jak dowodzą autorzy artykułu, bogactwo rozwiązań w dziedzinie projektów gier oraz inwencja samych graczy sprawiły, że wiele z tych definicyjnych założeń trudno obronić. Proponują więc oni własną definicję, która nie jest tak mocno związana z określonymi regułami rozgrywki i warunkami wygranej, a brzmi następująco: gra to „interaktywne cyfrowe doświadczenie, w którym gracz eksploruje warstwowe systemy mechanik, wizualności, dźwięków, sekwencji ruchomych, narracji i/lub interakcji społecznych"7.

O ile autorom udało się bardzo skutecznie dowieść wymykania się gier uznanym definicjom budowanym z różnorodnych perspektyw, o tyle sama ich definicja, mimo że ukuta dość niedawno, wydaje się podlegać pewnemu charakterystycznemu nastawieniu, które można by określić jako antropocentryczne. Definicja została bowiem sformułowana z perspektywy gracza. Tymczasem osiągnięcia zwrotu materialnego, który dotarł również do dziedziny gier wideo, pozwalałby na pewne uzupełnienia tych ustaleń i pokazanie takiego rozumienia aparatu gry, które uwzględniałoby kontekst posthumanistyczny.

Zwrot materialny w badaniach nad grami pozwala przede wszystkim na takie definiowanie środowiska gry, które uwzględniałoby jego szerszy kontekst niezwiązany jedynie z jej rozgrywaniem przez gracza. Ian Bogost $\mathrm{w}$ istotnej z perspektywy łączenia podejścia materialistycznego z analizą gier pracy Alien Phenomenology or What is Like to Be a Thing, wskazuje na przykładzie gry E.T.: The Extra-Terestial wydanej w 1982 na Atari, że gra jako materialny obiekt ma aż 10 ontologicznych kontekstów (jest m.in. porcją danych w pamięci ROM, kartridżem, dobrem konsumpcyjnym, systemem reguł i mechanik, przeżyciem interaktywnym, jednostką własności intelektualnej itd.) ${ }^{\mathbf{8}}$. Tylko niektóre z tych elementów ontologii związane są z typowymi definicjami gry i samym graczem. Zestaw ten pokazuje więc walory myślenia o grze w charakterze obiektu materialnego'.

7 Examining the Evolution..., s. 28.

8 I. Bogost Alien Phenomenology, Or, What It's Like to be a Thing, Posthumanities, University of Minnesota Press, Minneapolis 2012, s. 17-18; pozostałe "formy istnienia" gry to u Bogosta: przepływ modulowanych fal elektromagentycznych, zintegrowany obwód elektryczny pamięci ROM, przedmiot kolekcjonerski, znak kryzysu przemysłu gier w 1983 roku.

9 Zob. też: M. Felczak Przyjemność upodmiotowionych przedmiotów, Dziedzictwo brytyjskich studiów kulturowych, realizm spekulatywny i gry wideo, „Kultura Popularna” 2014 nr 39 (1), s. 82-101. 
Inne źródła wskazują, że możliwe jest także decentralizowanie samej pozycji gracza w definicjach gry. McKenzie Wark wprowadza do tego sposobu myślenia wątek, który można by określić jako przejaw krytyki antropocentryzmu na polu gier. Próbuje zdefiniować gracza w perspektywie samej gry:

Ostateczne pytanie związane z teorią gracza może łączyć się z wyjściem poza fenomen grania jako doświadczenia gracza w stronę postrzegania grania z punktu widzenia gry. ${ }^{10}$

Cytowany przez niego K-Punk pokazuje gracza jako ciąg ukierunkowanych impulsów" . Wark w innym miejscu wskazuje także, że gra jest „tym, co dręczy. Kształtuje gracza nie na swoje podobieństwo, ale w zgodzie z własnym algorytmem"12.

Aparat gry byłby w perspektywie tych obserwacji wielowarstwowym środowiskiem budowania interakcji, w którym, jak pokażą następne z omawianych poziomów, dochodzi do zmiany kierunków interakcji pozwalających na formowanie się różnych agentów i nieustającą zmianę dynamik między procesami technologicznymi i biologicznymi. Jest to bardzo ciekawe ujęcie w związku z tym, że „człowieczeństwo” gracza nie stanowi już centralnego aspektu definicji gry, a wręcz przeciwnie, możliwa jest perspektywa odwrotna: definiowanie gry jako obiektu niezależnego od gracza, której on tylko towarzyszy jako asamblaż afektów i funkcji biologicznych. Dobrze ten rodzaj podejścia podsumowuje Giddings wskazujący na cyborgiczne właściwości samego aparatu gry: „Światy gier zaludnione są mutantami, cyborgami, robotami i komputerowymi sieciami - awatary wyposażone są w nahełmowe wyświetlacze [headup displays], exoszkielety i niemożliwe rodzaje broni. Jednak gry mogą być postrzegane w znamienny sposób nie tylko jako reprezentacje domniemanej technokultury z przyszłości, jako technologiczne wyobrażenie

\footnotetext{
M. Wark Gamer Theory, Harvard University Press, Cambridge, MA 2009, s. 223.

Tamże.

Tamże, s. 222. Do podobnej perspektywy zdaje się odwoływać R. Ilnicki w tekście: Polskie gry komputerowe lat 9o. w perspektywie chaoestetyzacji, w: Sztuka i technologia w Polsce. Od cyberkomunizmu do kultury makerów, red. A. Jelewska, Wydawnictwo UAM, Poznań 2014, s. 125-149; por. cytat: „To już nie podmiot swoją aktywnością przecina nieskończone prędkości, wykrajając z nich bloki wrażeń, lecz programowanie doświadczenia sprawia, że to technicznie wytworzone bloki wrażeń konstruują efemeryczny podmiot", s. 125.
} 
nowych mediów, ale także jako aktualne instancje technokultury rozwijającej się tu i teraz"13.

\section{Poziom fabularny:}

Związki gier z posthumanizmem ujawniają się w najbardziej wyrazisty sposób na wspominanym przez Giddingsa poziomie fabularnym. To również najbardziej oczywisty poziom, na którym pojawia się bogactwo motywów i figur narracyjnych. Z uwagi na wielość tych kontekstów przekraczających nawet ramy osobnego tekstu w artykule zamiast analizy konkretnych wątków zamierzam wskazać jedynie główne prądy fabularne gier związane z ideologią posthumanistyczną i transhumanistyczną.

\section{Motyw cyborga i hybryd biologiczno-technologicznych}

Trudno byłoby podsumować stan i liczebność specyficznych dla gier postaci cyborgów, ponieważ zaludniają one większość z tytułów osadzonych w klimacie cyberpunku. Oprócz growych adaptacji filmów i utworów literackich, w których takie postaci się pojawiają (Terminator, Robocop itp.) można także wskazać na autorskie narracje z dziedziny gier. Warto tu wymienić zarówno cybernetycznie usprawnionego Johna-117 Master Chiefa z serii Halo czy Jaxa z Mortal Kombat posiadającego bioniczne ramiona. W Deus Ex główny bohater, agent JC Denton, może korzystać z różnorodnych „nanowszczepów” poszerzających jego możliwości. Pierwszoplanowa postać, którą steruje gracz w serii Mass Effect, idealnie odpowiada z kolei koncepcji cyborga Haraway jako istoty demistyfikującej kategorię płci. Commander Sheppard jest kobietą lub mężczyzną, w zależności od wyboru gracza, posiada też od drugiej części cybernetyczne implanty uzupełniające jej/jego ciało powołane do życia na nowo po śmierci.

\section{Motyw dominującej Al (singularity)}

W wielu tytułach spotkamy się z różnorodnymi wizjami Kurzweilowskiej „Osobliwości”. W System Shock oponentem głównego bohatera jest kierujący

13 S. Giddings Playing with Nonhumans: Digital Games as Technocultural Form, w: Worlds in Play: International Perspectives on Digital Games Research, ed. by S. De Castell, J. Jenson, Peter Lang, New York 2007, s. 115. 
stacją Citadel SHODAN, w Deus Ex potężną istotą, która ma możliwość opanowania całego świata, jest Helios. Z kolei ogarnięty nienawiścią do ludzkości przerażający computer AM z gry I Have No Mouth, and I Must Scream z 1995 roku stanowiącej adaptację opowiadania Harlana Elisona wymyślnie torturuje pięciu ostatnich reprezentantów rodzaju ludzkiego. Wielokształtna i potężna sztuczna inteligencja pojawia się także zarówno we wspominanych Deus Ex, jak i w Mass Effect czy Somie.

\section{Motyw modyfikacji genetycznych}

W stronę interesujących nurt transhumanistyczny genetycznych modyfikacji, psycho-stymulacji i mutacji organicznych kieruje się fabuła BioShock wzbogacona przy okazji o wątek konsekwencji etycznych związanych z modyfikacjami, które mają też wpływ na mutowanie ciała głównego bohatera w pierwszej części serii. Nabywa dzięki temu nowych umiejętności, takich jak telekineza itp. Klonowanie jest także akcentowane w fabule Metal Gear Solid, w której główni bohaterowie kolejnych części gry, Solid Snake i Liquid Snake (a także Solidus Snake), są genetycznymi klonami innej z istotnych postaci, Big Bossa.

\section{Motyw relacji międzygatunkowych}

Wiele gier, które wpisują się w złożony problem odpowiedzialności człowieka za rośliny i zwierzęta, zostanie omówionych w części poświęconej poziomowi genologicznemu, na którym pojawia się wiele charakterystycznych, podejmujących tę problematykę gatunków. Warto w tym miejscu przypomnieć, że podobny charakter ma m.in. gra Whiplash studia Eidos wyprodukowana w 2003 roku. Whiplash jest produkcją popularną, która z pewną dozą humoru odnosi się do problemu prowadzenia doświadczeń na zwierzętach laboratoryjnych, pokazując ucieczkę dwóch zwierzęcych bohaterów, łasicy i królika. Gra wywołała zaskakujące kontrowersje w Wielkiej Brytanii. Przedstawiciele policji i świata nauki wygłaszali sądy, że tytuł ten może przyczynić się do eskalacji ataków terrorystycznych mających na celu uwolnienie zwierząt laboratoryjnych ${ }^{14}$.

14 Zob. J. Hochschartner Animal rights on the Xbox: A video game for vegans. On its tenth anniversary, there's still no more pro-animal game than "Whiplash", (11.11.2013); http://www.salon. com/2013/11/11/animal_rights_on_the_xbox_a_video_game_for_vegans/ (15.11.16) 
Motyw odpowiedzialności za zwierzęcych innych pojawia się także w artystycznych projektach gier. Madeleine Boyd jest autorką ciekawego projektu zwracającego uwagę na wyzysk koni wyścigowych w Australii i na niepewność ich losów. Jej instalacja „Game of horseshoes for the Anthropocene” z 2013 roku składa się z klasycznej gry w podkowy, która została doposażona w ekran, na którym ukazywały się komunikaty na temat dalszych losów koni biorących udział w gonitwach. W zależności od tego, w jakim miejscu padały podkowy rzucane przez odbiorców instalacji, ukazywały się inne komunikaty, np. o tym, że koń zginął na torze, że trafił na sprzedaż, był zmuszony do udziału w kolejnych wyścigach czy, jeśli mu się poszczęściło, został wykupiony do klubu jeździeckiego dla dzieci. Samą instalację autorka określa jako grę poważną ${ }^{15}$.

\section{Gry ekologiczne (motyw antropocenu)}

Odczuwanie świata jako całości jest charakterystycznym motywem myślenia nurtów ekologicznych. Podobny wydźwięk ma kilka kolejnych gier, np. SimEarth: The Living Planet studia Maxis, już z 1990 roku, w której gracz ma wpływ na elementy ekosfery: temperaturę, atmosferę, geosferę, może także rozwijać różne formy życia na planecie. Na uwagę zasługuje także Garden of Life studia The You Company. Użytkownik tej gry znajduje w kosmosie fragment zniszczonej planety „Wellness”, na której może odtworzyć jej florę. Wspiera go w tym magiczne drzewo Yuko. Podobny charakter mają niektóre tytuły edukacyjne, np. Earth: A primer. Jest to rodzaj interaktywnej książki na temat różnorodnych procesów geologicznych. Użytkownik tej aplikacji ma wiele swobody w manipulowaniu tymi procesami, może tworzyć wulkany, formować pasma górskie, żłobić skały wiatrem, zalewać wybrane tereny morzami i pokrywać je lodowcem ${ }^{16}$. Omawiane gry cechują się podwójną relacją do idei posthumanistycznej. Z jednej strony są przejawem misyjnych nadziei o zrównoważonym świecie, w którym ludzkość zachowuje się odpowiedzialnie wobec natury, z drugiej symbolizują sprawczą moc antropocenu, gracz ma

M. Boyd A game of horseshoes for the Anthropocene: the matter of externalities of cruelty to the horseracing industry Animals in the Anthropocene: Critical Perspectives on Non-human Futures, w: Animals in the Anthropocene: Critical perspectives on non-human futures, Animal Publics, ed. by Human Animal Research Network Editorial Collective, Sydney University Press, Sydney 2015. 
bowiem pełną swobodę w modelowaniu warunków życia na symulowanej planecie.

Prezentowane w tej części artykułu w sposób bardzo zdawkowy motywy w każdym z wymienionych tytułów obejmują nieco inny zakres. Raz jest to motyw przewodni fabuły, ukształtowanej w formę transhumanistycznej cyberpunkowej utopii, innym razem jedynie opcja ukształtowania naszego protagonisty, jeszcze kiedy indziej to tylko prosty atrybut lub rekwizyt postaci dający jej unikalną umiejętność.

\section{Poziom genologiczny}

Na poziomie genologicznym warto skupić się na tych gatunkach i odmianach gier, które w swojej definicji wykazują związki z ideą posthumanistyczną. Bezpośrednie nawiązania tego typu ujawniają się oczywiście w nurcie gier z obszaru artificial life. Dysponujemy w tej chwili rozbudowanym zestawem gier tego typu, które mają również swego rodzaju podgatunki i specyficzne konteksty. Warto wymienić tu zarówno wirtualne zwierzęta, które są przedmiotem zainteresowań psychologów, np. Sherry Turkle" ${ }^{17}$,jak również oscylujące wokół gier poważnych symulacje biologiczne, a także symulacje społeczne w stylu bardzo popularnego The Sims ${ }^{18}$.

Jeśli mowa o wirtualnych zwierzętach, to mamy tu do czynienia zarówno $\mathrm{z}$ wykorzystaniem postaci realnych zwierząt, np. w serii Petz czy w formie robota terapeutycznego Paro, jak również ze zwierzętami wymyślonymi, np.Tamagochi czy sprzedawane w postaci zabawek Furbies. Pośród bogatej kolekcji zwierząt wirtualnych warto skupić się szczególnie na tych, które odwołują się bezpośrednio do krytyki antropocentryzmu. Seaman wyprodukowany na platformę Sega Dreamcast w 1999 roku jest szczególnym rodzajem wirtualnego zwierzęcia, które mocno wpisuje się w ideę biologicznej hybrydowości i w sugestywny sposób komentuje ideę postczłowieka. W grze mamy bowiem do czynienia z osiągającym kolejne stadia ewolucji morskim organizmem,

S. Turkle Samotni razem. Dlaczego oczekujemy więcej od zdobyczy techniki, a mniej od siebie nawzajem, przeł. M. Cierpisz, Wydawnictwo UJ, Kraków 2013.

Sporo gier z obszaru artificial life określanych jest także jako raising simulations (symulacje hodowlane lub może lepiej symulacje wychowania), w których akcentuje się dorastanie wychowywanego osobnika lub rozwijanie się jego kariery, ponieważ część z takich gier polega na wsparciu postaci nie w biologicznym, ale w społecznym (zawodowym) rozwoju, por. np. Idolmaster wydany przez Bandai Namco w 2005 roku. 
który otrzymał ludzką twarz i potrafi zwracać się do gracza z pytaniami, popisywać przed nim wiedzą, a także obrażać go.

Symulacje biologiczne są kolejnym z interesujących podgatunków artificial life. Więcej jest tutaj zaawansowanych i poważnych tytułów, pośród których znajdziemy m.in. SimCell i Cell Life zapoznające gracza ze strukturą tkanek i komórek. Do tej podgrupy warto zaliczyć także bardziej popularne, przeznaczone dla szerszego grona odbiorców tytuły, w których zadaniem gracza jest wspieranie ewolucji grupy stworów np. Spore i Creatures. Są to rozbudowane produkcje, ale gry ewolucyjne mogą mieć także swoją casualową wersję, na urządzenia mobilne. Celują w ich tworzeniu studia Tapps Games, Diced Pixel czy Erow.dev. Chodzi o gry, w których gracz opiekuje się farmami bezustannie mutujących stworzen. Mogą to być zwierzęta, np. kurczaki, ośmiornice, króliki, ale także ludzie, emotikony, naklejki czy nawet mutujące (!) jedzenie. W tej chwili kartoteka sklepu Google Play liczy 24 takie tytuły.

Cechą wspólną wielu gier z gatunku artificial life jest skłanianie graczy do dyskusji na temat statusu wirtualnych agentów oraz wykształcenie się specyficznych rytuałów społeczno-kulturowych, które zostaną omówione w dalszej części artykułu.

Bardzo ciekawym gatunkiem gier w perspektywie dyskusji nad antropocentryzmem i hegemonią wobec zwierząt są różnorodne symulatory zwierząt, w których ujawniają się także interesujące konteksty związane z animal studies i nowym animizmem, np. Shark Simulator, Wolf Simulator, Bear Simulator, Savanna Run, Omawiane tytuły pokazują wiele ukrytych elementów biopolitycznej hegemonii wobec zwierząt, dzięki czemu mogą stać się wartościowym materiałem analitycznym dla krytycznie zorientowanego posthumanizmu. Symulatory te najczęściej nie mają wiele wspólnego z symulowaniem rzeczywistych zachowań zwierząt, a raczej wykorzystują ich postaci do kreowania malowniczych pojedynków z innymi zwierzętami, z którymi w naturze te w ogóle nie walczą, albo z ludźmi. W Angry Shark Simulator $3 d$ gracz steruje awatarem rekina, dokonując agresywnych mordów na pływakach i wędkarzach na łodziach. Można więc uznać, że twórcy tego typu gier dokonują zawłaszczenia postaci zwierząt, kreując je na krwiożercze monstra i „przystosowując" tego typu postaci do roli protagonistów w grach (tworzonych na podobieństwo „ludzkich” herosów). Pośród symulatorów zwierząt można jednak czasem znaleźć gry o wydźwięku edukacyjnym, w których twórcy stosują mniej instrumentalne podejście i starają się odtworzyć realne warunki funkcjonowania zwierząt. Taki charakter mają np. gry The Wolfi The Lion dystrybuowane już w połowie lat 9o. przez Sanctuary Woods oraz dużo 
późniejszy WolfQuest wydany przez Eduweb w 2007 roku. Zupełnie inną strategię przyjęli twórcy satyrycznego Goat Simulator, w którym sterowana przez gracza koza jawi się w zasadzie jako „zwierzę krytyczne" dokonujące zniszczenia pośród rodzaju ludzkiego i podkopujące antropocentryczną perspektywę pozostałych symulatorów.

W ramach poziomu genologicznego warto także zwrócić uwagę na różnorodne symulacje elementów natury, które zdają się wykazywać związki $\mathrm{z}$ nurtem nowego materializmu i nowego animizmu, $\mathrm{np}$. The Mountain i The Rock Simulator. The Mountain O'Reilly'ego jest jednym z przykładów nurtu określanego jako nie-gry (non-games) ${ }^{19}$. W grze użytkownik powoduje wyłonienie się z niebytu góry, która staje się dla gracza źródłem niecodziennych doświadczeń i zmiany sposobu myślenia. Ów specyficzny symulator jest próbą zarysowania nie-ludzkiej perspektywy formowanej z "punktu widzenia” wielkiego naturalnego obiektu. The Rock Simulator wydaje się w tych funkcjach podobny do The Mountain, choć twórcy wzbogacili tę grę o serię minigier, w których zwyczajowo nieruchomy obiekt, jakim jest kamień, może być sterowalny przez gracza i musi np. pokonać przeszkody na trasie z urwiska. Jest więcej tytułów, w których twórcy wykorzystują interesujące napięcie między nieagentywnym, nieporuszającym się obiektem, a typową dynamiczną konwencją gry, w której powinien znaleźć się jakiś pokonujący przeszkody agent-bohater. W I'm Bread takim obiektem jest kromka chleba, która wykonuje różne „czynności”, aby dostać się do tostera. Co charakterystyczne, ten szczególny protagonista nie jest w grze antropomorfizowany, ale posiada "agentywną" właściwość - potrafi przemieszczać się w oryginalny sposób.

W kontekście relacji międzygatunkowych warto również omówić szczególny casus symulacji randkowych oraz innych typów gier (głównie japońskich), w których pojawiają się możliwości budowania romantycznych relacji z przedmiotami i zwierzętami (np. Tectr, PacaPlus, Hot Date). Omawiane gry wydają się powstawać m.in. na fali coraz szerszej świadomości istnienia nowej seksualnej mniejszości, jaką są tzw. obiektofile. Wspólnota Objectum Sexuals nastawiona jest na budowanie intymnych relacji z przedmiotami. Czasem są to niewielkie obiekty, takie jak organy kościelne czy samochody, a czasem duże obiekty architektoniczne, takie jak Mur Berliński, Most Golden Gate w San Francisco czy Wieża Eiffela, czasem wreszcie adresatem uczucia są obiekty niematerialne. W grze ów motyw miłości do obiektów

19 Zob. np. P. Schreiber Eksperymentalne komputerowe gry tekstowe lat 90. a ruch notgames, "Homo Ludens" 2014 nr 1 (6), s. 131-140. 
zostaje najczęściej potraktowany satyrycznie w Tectr zaprojektowany przez Silverstring Media w czasie ostatniego Global Game Jamu (2016) jest grą randkową, w której gracz ma możliwość podrywania obiektów architektonicznych, np. wieżowców, domków letniskowych, basenów, ogrodów, a nawet panoptykonu. Z kolei w Hot Date obiektem flirtów jest uroczy mops, natomiast w PacaPlus jest nim przypominająca lamę alpaka (w którą zmieniła się ukochana głównego bohatera). Wiele gier z kręgu azjatyckiego przynosi kolejne niecodzienne obiekty pożądania wpisujące się w konwencje posti transhumanistyczne. W Tomak: Save the Earth wybranką gracza jest Bogini Evian, która zstępuje na Ziemię w postaci głowy „zasadzonej” w doniczce (!). W Creature to Koi Shiyo! główny bohater próbuje poderwać koleżankę z klasy, którą jest humanoidalny karaluch, w Hatoful Boyfriend uczennica podejmuje romantyczne relacje z gołębiami, a w Jurassic Heart obiektem miłości są dinozaury. W przygodówce Paradigm Jacoba Janerki zagnieżdżona została gra randkowa Post apoc dating sim, w której można umówić się z tosterem. Warto zwrócić uwagę także na Katawa Shoujo, w której głównego bohatera otaczają niepełnosprawne dziewczyny, m.in. Emi Ibarazaki pozbawiona dolnej części nóg sprinterka wyposażona w protezy podobne do tych, których używał Oscar Pistorius.

\section{Poziom agentywności i mechaniki gry}

Na poziomie agentywności i mechaniki warto przytoczyć ustalenia związane z traktowaniem aparatu gry jako mechanizmu napędzanego zarówno agentywnością gracza jak i skryptami sztucznej inteligencji. Środowisko gry często ujmowane jest jako sieć relacji różnych agentów. Jak wskazuje Brendan Keogh, „podmiotowe ja gracza jest redystrybuowane w czasie rozgrywki w posthumanistycznej sieci ludzkich i nie-ludzkich ciał i agentywności. Idea tego, kim jest gracz, jest jednocześnie kształtowana i poszerzana przez grę, pomiędzy technologicznym interfejsem a prezentowanym fikcyjnym światem" 20 .

Często poruszanym w tym obszarze problemem jest kwestia samodzielności gracza w grze. Pojawiają się tezy, że agentywność nie jest wolną wolą grającego, ale stanowi wypadkową oczekiwań gracza i modelu

20 B. Keogh Cybernetic memory and the construction of the posthuman self in videogame play, w: Design, Mediation, and the Posthuman, ed. by D.M. Weiss, A.D. Propen, C E. Reid, Lexington Books, Lanham 2014, S. 235. 
obliczeniowego proponowanego w grze. Wardrip-Fruin, Mateas, Dow, Sali, dokonując przeglądu stanowisk na temat agentywności w grach, wysuwaja cztery następujące postulaty: agentywność wyłania się z interakcji z systemem gry, który podpowiada możliwości graczowi; projektanci gry muszą wypośrodkowywać między agentywnością wymuszaną prawdopodobieństwem świata przedstawionego a wolą gracza; wstępne przeczucia gracza formowane na podstawie doświadczeń z codziennego świata i poprzednich gier konfrontowane są z ukrytym modelem działania w grze, co wpływa na fenomen agentywności; poczucie bycia w realnej sytuacji ma decydujące znaczenie dla agentywności, agentywność nie jest w trakcie gry realizacją wstępnego planu i założeń gracza, ale improwizacją, dla której ten plan jest źródłem²1.

Powyższe argumenty pokazują, że na omawianym poziomie zacierają się w pewien sposób granice między graczem a grą. Na nowo definiowane są także role gracza i gry, np. w kontekście automatów i oprogramowania, które bez udziału „ludzkich" graczy uczestniczą w rozgrywce, nabywając umiejętności z pola machine learning (np. Google DeepMind) lub reprezentując krytyczne podejście do technologii i sztuki nowych mediów (projekt Arduino Plays Timberman). Tym samym agentywność w grach wpisuje się w ramy teorii aktora-sieci.

Giddings pokazuje jeszcze inne konteksty agentywności w grach w świetle teorii ANT. Posługuje się kategorią technologicznej agentywności, by wskazać, że akt rozgrywania gry komputerowej jest „dystrybucją i delegowaniem agentywności między technologiami a graczami"22. Opierając się na teorii systemów intencjonalnych Dennetta, pokazuje także, że gracze traktują nie-ludzkich agentów jako takich, którym intencjonalnie przypisuje się ludzkie zachowania. Dzieje się tak dlatego, że wirtualni przeciwnicy wyposażeni są w skrypty sztucznej inteligencji na tyle złożone, że nie da się ich pojąć inaczej, niż przypisując im pożądania i intencje.

Dialektyka między kontrolą gracza nad agentami w grze a ich swobodą jest również bardzo ciekawym zagadnieniem lokującym się w obszarze projektowania gier, który ma wpływ na planowanie dynamiki rozgrywki. Problem ten ciekawie „rozgrywany” jest przez wybrane tytuły. Zakres stopnia autonomii postaci pojawia się np. jako opcja w The Sims i znacząco wpływa

21 N. Wardrip-Fruin, M. Mateas, S.P. Dow, S. Sali Agency Reconsidered, w: Proceedings of the Conference on Digital Games Research (DiGRA'og), London, UK, 2009, s. 7-8. 
na kształt rozgrywki. Problemy te są szczególnie wyraziste, kiedy weźmiemy pod uwagę te tytuły gier, w których bohater bezpośrednio sterowany przez gracza wspomagany jest niezależnymi pomocnikami. Jeśli stają się oni zbyt inteligentni i samodzielni, spada poczucie agentywności u gracza, a kiedy nie są oni zbyt samodzielni, powstaje wrażenie, że się ich tylko eskortuje. Innym przykładem relacji między graczem i bohaterem może być Walking Dead, w której Lee często jedynie w ogólnym zarysie reaguje na komendy gracza, prowadzi czasem swoje własne dialogi nie do końca odpowiadające linii dialogowej wybranej przez użytkownika gry ${ }^{\mathbf{2 3}}$. Warto tutaj wspomnieć także o grze Project Automata, której autor dowodzi, że w jego projekcie kreowane przez graczy miasta dysponują swego rodzaju zaprogramowanymi osobowościami. Można by więc o warstwie mechaniki gry mówić w tym projekcie jako o posthumanistycznym „innym”.

\section{Poziom interfejsu}

Poziom interfejsu jest wart omówienia w kontekście rozumienia aparatu gry jako asamblażu biologiczno-technologiczno-informacyjnego. Obecne stadium technologii cyfrowych pozwala coraz śmielej myśleć o rozwiązaniach rodem z Existenz Cronenberga i powiązać obszar gier z wybranymi aspektami biotechnologii i neurotechnologii. Większe zwrócenie uwagi na ciało gracza we współczesnej refleksji teoretycznej nad grami pozwala także na powiązanie tego obszaru z feministycznie zorientowanym nurtem posthumanizmu, krytycznym wobec kategorii płci i integralności ciała biologicznego.

Obecnie mamy do czynienia z całym „festiwalem” rozwiązań i praktycznych pomysłów na transhumanistyczne interfejsy gier. Zanim przejdę do omówienia wybranych rozwiązań technologicznych, warto na początku prześledzić definicję transhumanistycznych interfejsów w sytuacji, w której bardzo szybli postęp technologiczny w dziedzinie technologii gier ustanawia coraz to nowe standardy i to, co jeszcze niedawno wydawało się eksperymentalnie nowe, np. interfejsy kinetyczne czy technologia VR, staje codziennością graczy. Wydaje się, że mówienie o interfejsach gier w perspektywie transhumanistycznej wiąże się z potrzebą definiowania ich technologii jako takiej, która intensywnie penetruje ciało i omija tradycyjne formy interakcji z gra za jego pośrednictwem w stronę neurokomunikacji. Warto również wskazać,

23 Zob. A. Duncan My Second Self: Understanding the Relationship between Players and Avatars, 9.03.2014. https://theanimistblog.wordpress.com/ (5.11.2016). 
że o transhumanistycznych interfejsach będziemy mówić wtedy, kiedy pozwalają one przełamać kognitywne ograniczenia graczy, np. tych którzy są niepełnosprawni.

W obszarze tym odbywają się obecnie intensywne eksperymenty. Pierwsze pole, które badane jest w kontekście gier, to budowanie alternatywnych systemów sterowania w grach związanych z wykorzystaniem aktywności elektrofizjologicznej mózgu. Tak zwany neurogaming rozwijany jest głównie przy użyciu systemów EEG. Pośród zrealizowanych w tym obszarze projektów warto wymienić np. NeuroRacera opracowanego w Gazzaley Lab w San Francisco ${ }^{24}$, która to gra wspiera umiejętności kognitywne osób starszych. Dzięki interfejsowi mózgowemu rozwijanemu przez zespół badaczy z Uniwersytetu w Grazu można natomiast rozegrać sesję w World of Warcraft. System EEG Emotive Epoc został w jednej z eksperymentalnych gier połączony z Kinectem. Powstają też coraz bardziej zaawansowane produkcje bezpośrednio przeznaczone dla systemów EEG, takie jak NeuroMage - gra o magach, których czary i moce może kontrolować umysł gracza. Po okresie eksperymentów z drogimi na początku interfejsami EEG wchodzimy obecnie w fazę upowszechniania się tego typu sprzętu. Kompania NeuroSky oferuje już systemy za mniej niż 200 \$, a ich mobilne wersje za niecałe 100 \$. Ta sama firma zachęca także do zakupu sporej kolekcji neurogier, w której znalazły się m.in. Invaders Relaoded, przypominający oryginalnych Invadersów, Dagaz, w którym za pomocą umysłu układamy wymyślne mandale, czy nawet gry sportowe w stylu Jurassic Golf.

Pośród innych innowacyjnych interfejsów znajdziemy także systemy wykorzystujące śledzenie ruchu gałek ocznych (eyetracking). System eyeX firmy Tobii pozwala "oczyma” zagrać w kilka przystosowanych do obsługi tego interfejsu gier np. Watch Dogs 2, Deus Ex, Assassins Creed Rouge czy Farming Simulator. Tworzone są też gry specjalnie przeznaczone na to urządzenie, np. Son of Nor, Refelections czy Spectrophobia. System ten wydaje się idealnym rozwiązaniem dla osób niepełnosprawnych, niemających możliwości poruszania rękoma, ale jego twórcy zachwalają raczej jego możliwości dla osób zdrowych w kontekście nowych doznań, pogłębiania immersji (środowisko reagujące na wzrok gracza) czy łatwiejszego celowania do przeciwników i przesuwania ekranu.

24 J.A. Anguera et al. Video Game Training Enhances Cognitive Control in Older Adults, "Nature” 4.10.13, 501, nr 7465, s. 97-101. 
Obiecujące dla rozwoju transhumanistycznych interfejsów gier są obecnie również tzw. systemy TVSS (Tactile-Visual Substitution Systems). Mamy tu do czynienia z technologią, która pozwala zastępować obraz bodźcami dotykowymi, dzięki czemu m.in. osoby niewidome są w stanie dotykowo odtworzyć wybrane obrazy. Wynalazcą tej technologii jest Paul Bach-y-Rita, a środowisko badaczy, którzy ją obecnie rozwijają, wielokrotnie postuluje wykorzystanie tej technologii w przemyśle gier skierowanych do osób niewidomych ${ }^{25}$. Istnieją także pierwsze próby wykorzystania tej technologii do symulowania przestrzeni 4-wymiarowych w grach ${ }^{26}$.

\section{Posthumanistyczne praktyki grania}

Ostatni poziom związany z praktykami grania ujawnia afektywną naturę rozgrywki, w której możliwe jest budowanie intymnych relacji między graczem i postaciami w grze. Mamy tu do czynienia ze zróżnicowanymi i wysublimowanymi manifestacjami empatii i antypatii, np. w odniesieniu do wirtualnych zwierząt oraz do innych bohaterów gier²

W wielu przypadkach są to akty nienawiści i wzgardy wobec wirtualnych postaci, dzięki którym ujawnia się także w ciekawy sposób dyskusja nad ich ontologia. Najbardziej charakterystycznym przykładem tego typu interakcji z bohaterami gry jest celowe męczenie i eksterminowanie postaci w grze Sims. Bogaty arsenał środków ich zabijania rozciąga się od budowania

25 Zob. np. M. Tyler, K.A. Kaczmarek Seeing with the Brain, "International Journal of Human-Computer Interaction" 2003, No. 15 (2), s. 285-295 oraz M. Ptito, D.-R. Chebat, R. Kupers The blind get a taste of vision, w: Human Haptic Perception: Basics and Applications, ed. by M. Grunwald, Springer Science \& Business Media, Basel-Boston-Berlin 2008, s. 481-489.

Zob. wątek Could you train yourself to perceive 4 spatial dimensions? na forum biohack.me, 8.08.16, http://forum.biohack.me/discussion/comment/20533\#Comment_20533 (1.11.2016).

27 O afektywnym stosunku do nie-humanistycznych podmiotów kreowanych w grach w kontekście analizy takich tytułów jak The Stanley Parable i The Talos Principle pisze P. Kubiński. Por. fragment: „Sądzę, że zwłaszcza z analizy dwóch ostatnich przykładów wyłania się obraz gier wideo jako medium szczególnie predysponowanego do przedstawiania jak najbardziej współczesnej problematyki związanej ze sztuczną inteligencją czy podmiotami innymi niż ludzie. Gra wideo - w przeciwieństwie do mediów nieinteraktywnych, takich jak tradycyjny film - pozwala nie tylko obserwować działania takich agentów, lecz także się w nich wcielać i kierować ich działaniami, a więc przyjmować wobec nich szczególną postawę, wyjątkowo sprzyjającą empatii, w: tegoż Dyskurs filozoficzny w grach wideo. Wybrane konteksty w grach Wiedźmin 3: Dziki Gon, The Stanley Parable oraz The Talos Principle, „WIELOG ŁOS. Pismo Wydziału Polonistyki Uj" $2015 \mathrm{nr} 3$ (25), s. 97-110. 
basenów, z których nie ma wyjścia, przez podpalanie tych wirtualnych agentów, aż po budowanie wymyślnych scenariuszy i przestrzeni, w których są oni torturowani i poniżani. Interesujące obserwacje płyną z analizy forów, na których ten temat się pojawia. Dyskusje graczy pokazują, że sprzeciw wobec tego typu praktyk bądź ich akceptacja wiąże się także ze zniuansowanym definiowaniem statusu ontologicznego wirtualnych istot. Okrucieństwo graczy jest często usprawiedliwiane "pikselową" naturą Simów i ich nie-człowieczeństwem, ale z drugiej zaskakująco bliskie jest Agambenowskim ideom obozu, stanu wyjątkowego czy „muzułmana”28.

Oprócz nienawiści pojawiają się również znamienne przejawy empatii. Głośna była jeszcze kilka lat temu historia związana z grą Creatures. Pośród użytkowników tego tytułu znalazła się spora grupa takich, którzy kreowane stworzenia traktowali w sposób sadystyczny lub je po prostu zaniedbywali. Jeden z takich graczy o nicku AntiNorn założył nawet stronę poświęconą torturom Nornów. Wywołało to oburzenie sporej liczby członków społeczności graczy, którzy zawiązali nawet Federację Przeciwko Nadużyciom Sztucznego Życia. Dla torturowanych Nornów empatyczna część graczy przygotowała też swego rodzaju klinikę przywracającą zdrowie i kondycję tych wirtualnych stworzeń.

Jeszcze dalej w manifestowaniu empatii wobec wirtualnych postaci posunął się jeden z użytkowników gry randkowej Love Plus dostępnej na konsoli Nintendo DS. Posługujący się pseudonimem Salgooo poślubił w trakcie ceremonii transmitowanej na żywo w sieci bohaterkę gry Nene Anegasaki. Ślub ten, który doczekał się youtubowych parodii i niewybrednych komentarzy w sieci, wydaje się świadectwem potrzeby formalizowania takiego rodzaju intymności, który obejmuje sferę nie-ludzkiego. Choć podobny pigmalioniczny motyw znajdziemy i u Gibsona w literackiej Idoru i ostatnio u Spike Jonze'a w filmowej Her, to przypadek Salagooo pokazuje, że nie-ludzkie obiekty miłości mogą pojawić się nie tylko w fabularnych opowieściach, ale i w codziennym życiu. Ślubowi Sala bardzo blisko do wspominanej społeczności obiektofilów.

Omawiane empatyczne praktyki kulturowe stanowią eksperymentalną próbę społecznego usankcjonowania intymności budowanej wobec „informacyjnych bliskich", są także wydźwiganiem wirtualnych agentów do roli

28 Szerzej zobacz rozdział pt. The Sims i definiowanie podmiotu przez okrucieństwo, w: J. Stasieńko Niematerialne Galatee w wehikułach rozkoszy i bólu, technologie mediów jako aparaty kreowania posthumanistycznej intymności, WN Katedra, Gdańsk 2015. 
pełnoprawnych podmiotów. Z drugiej strony ujawniające się na tym samym poziomie wysublimowane formy okrucieństwa graczy wobec bohaterów gier uruchamiają interesującą dyskusję na temat statusu ontologicznego tych postaci.

\section{Podsumowanie}

Określone w niniejszym artykule poziomy obecności aspektów posthumanistycznych w grach i ich „podatności” na ten typ refleksji zostały jedynie zarysowane po to, by unaocznić bardzo bogate „złoża” tematów, toposów i wątków. Posthumanizm w grach będzie oznaczał zarówno cyborgiczną naturę aparatu, jak i zdecentralizowaną pozycję gracza, który nie jest już nadrzędnym dysponentem gry, ale może być także traktowany jako jej biologiczny operator, nie zawsze biologiczny i nie zawsze niezbędny do jej rozegrania. Nieantropocentryczna koncepcja gracza uwzględniałaby także jego bardziej intymny $i$ afektywny stosunek zarówno do własnego awatara w grze, jak i do innych postaci, wobec których buduje on różnego rodzaju protokoły porozumienia i konfliktu albo przyjmujące formę często emergentnych strategii gry, albo wychodzące poza środowisko gry, stając się eksperymentalnymi rytuałami w sferze społecznej, w których manifestuje się chęć użytkowników gier do formowania nowych dla tej sfery podmiotów.

Gra jawi się w tej perspektywie jako przedmiot zainteresowań ontologii zorientowanej na przedmioty wtedy, kiedy gracz jest ujmowany jako efekt gry, a nie jej demiurgiczny hegemon. Środowisko gry może być z drugiej strony postrzegane jako miejsce wcielonych w przedmioty techno-duchów wtedy, kiedy gracze podejmują wysiłek traktowania ich jako niezależnych agentów. Post/transhumanistyczny aparat gry w części z omawianych projektów i interfejsów może się także jawić jako środowisko wyzwolenia od ograniczeń niedoskonałego ciała gracza, przy czym, co paradoksalne, tyle upatruje się w nim nadziei, ile wykazuje się jego ograniczeń i dyskryminujących uproszczeń. Środowisko osób niepełnosprawnych wciąż wskazuje na schematyczność postaci z niepełnosprawnościami w grach, postulując budowanie bardziej pogłębionych sylwetek bohaterów i wnikliwsze przyjrzenie się specyfice określonych form niepełnosprawności, które nie muszą być jedynie uciążliwościami dla story designerów, ale pozwalają wyzyskać nowe szanse na niespotykane i oryginalne wątki fabularne.

Przedstawione konteksty post- i transhumanistyczne w grach nie wyczerpują możliwych do omówienia tropów. Wart osobnego zbadania jest np. 
doping technologiczny w e-sporcie. Sfera profesjonalnego gamingu może się $\mathrm{w}$ ten sposób doczekać prowadzonych z transhumanistycznej perspektywy omówień podobnych do tych, które dotyczą sportu olimpijskiego autorstwa Andy Miaha ${ }^{29}$. Niektóre z wydawać by się mogło typowych gier zaczynają być analizowane także w kontekście idei związanych z posthumanizmem. Hanah Gould omawia np. Pokemon Go w perspektywie techno-animizmu ${ }^{30}$. Trudno było również odnieść się w artykule do bardzo rozbudowanego dorobku informatyki sztucznej inteligencji na potrzeby gier. Tu również powstaje sporo rozwiązań, które mogą być bliskie ideom Kurzweila. Te wszystkie sygnały pokazują, że w posthumanizmie tkwi istotny potencjał dla gier, z którego będą w najbliższym czasie korzystać zarówno ich badacze, jak i projektanci.

29 Zob. np. A. Miah Bioethical Concerns in a Culture of Human Enhancement, w: Encyclopedia of Sports Medicine, Genetic and Molecular Aspects of Sport Performance, ed. by C. Bouchard, E. Hoffman, International Olympic Committee, Lausanne 2011, s. 383-392, oraz tegoż The Ethics of Human Enhancement in Sport, w: Handbook of Research on Technoethics, ed. by R. Luppicini, A. Rebecca, Idea Group Publishing, Hershey, PA 2009, s. 69-84.

H. Gould If Pokémon Go feels like a religion, that's because it kind of is. From its animist origins to its relationship with tech and capitalism, the game has more in common with religion than you might expect, "The Guardian" 12.07.16, https://www.theguardian.com/technology/2016/jul/12/ pokemon-go-addictive-game-shares-much-with-religious-devotion (25.10.2016). 


\section{Abstract}

\section{Jan Stasieńko}

UNIVERSITY OF LOWER SILESIA

Automantons, Hybrids, Affects: The Apparatus of Computer Games, Gaming Practices and Their Post-Humanist Contexts

Stasieńko discusses how the idea of post-humanism is used in the practice of creating and analysing games. The question is discussed on several levels, such as game apparatus, plot, genre, agency in the game and the game's mechanics, interface and gaming practices. Proposing a definition of video games that avoids anthropocentrism and allows to take into account the different contexts of post- and transhumanism, Stasieńko also points to the benefits of such a critical perspective when it comes to studying computer games and gaming practices in terms of the mutual and often affective relationship between the player and the game apparatus, as well as the hybridity and cyborg-like status of such a biological-IT assemblage.

\section{Keywords}

posthumanism, computer games, affect, transhumanist themes in games, new materialism 